\title{
CLINICAL AND LABORATORY EVALUATION OF A NEW INHALATION ANAESTHETIC: FORANE* (COMPOUND 469) $\mathrm{CHF}_{2}-\mathrm{O}-\mathrm{CHClCF}_{3} \dagger$ \\ (1-chloro-2,2,2-trifluoroethyl difluoromethyl ether)
}

\author{
Allen B. Dobkin, M.D., Peter H. Byles, M.B., Sion Ghanooni, M.D., \\ and Dominiciano A. Valbuena, M.D. 克
}

BECAUSE OF THE occasional reports of toxicity to vital organs with halothane and methoxyflurane, we have screened a large number of halogenated compounds in the hope of finding a safer inhalation anaesthetic. The aim of our search was to find a compound that was non-flammable, non-explosive, chemically stable, volatile, and having a pleasant odor. The compound sought was also to have a high anaesthetic potency, yet a wide margin of safety (i.e., large ratio of dose for surgical anaesthesia to that causing respiratory and cardiac arrest). Further, it was to be compatible with epinephrine and free from neuromuscular or central nervous system irritation.

The most promising agent tested to date is $\mathrm{CHF}_{2}-\mathrm{O}-\mathrm{CHClCF}_{3}$, Air Reduction Company's Compound 469 (Forane ${ }^{*}$ ). It is an analogue of Ethrane ${ }^{*}$, ${ }^{1}$ having the same molecular weight, a lower boiling point, and a higher vapor pressure. Oil/ gas, blood/gas, and water/gas partition coefficients are lower, while oil/water is somewhat higher than Ethrane (see Table I). The vapor has a hardly perceptible ethereal odor.

This compound was studied in detail in several species of small and large mammals. In addition, compatibility tests were carried out with muscle relaxants and other drugs used routinely during anaesthesia. Inclusive comparison of this compound with fluroxene, halothane, methoxyflurane, and Ethrane, made with special reference to hepatic and renal pathology and blood chemistry in healthy and stressed beagle dogs, mongrel dogs, and rhesus monkeys, showed that it was free of toxic effects. It produced anaesthesia rapidly in all animals tested without the neuromuscular effects seen with Ethrane; its action was rapid like halothane and Ethrane, it had strong analgesic and muscle-relaxing properties like fluroxene, methoxyflurane, and Ethrane. It did not cause appreciable or persistent ventricular arrhythmias when dogs were challenged with epinephrine, and mongrel dogs tolerated apnoeic oxygenation for 30 minutes without evidence of physiological deterioration. ${ }^{2,3}$

When we were completely satisfied that Forane was at least as safe as halo-

*Trademark of Air Reduction Company, Inc., Murray Hill, New Jersey.

FFrom the Department of Anesthesiology, State University Hospital, State University of New York, Upstate Medical Center, 750 East Adams Street, Syracuse, New York 13210.

\$This work was supported in part by the Division of Research Facilities and Resources of Nir through Grant Fr 00353 and by the Ohio Medical Products Division of Air Reduction Company, Inc, Madison, Wisconsin. 


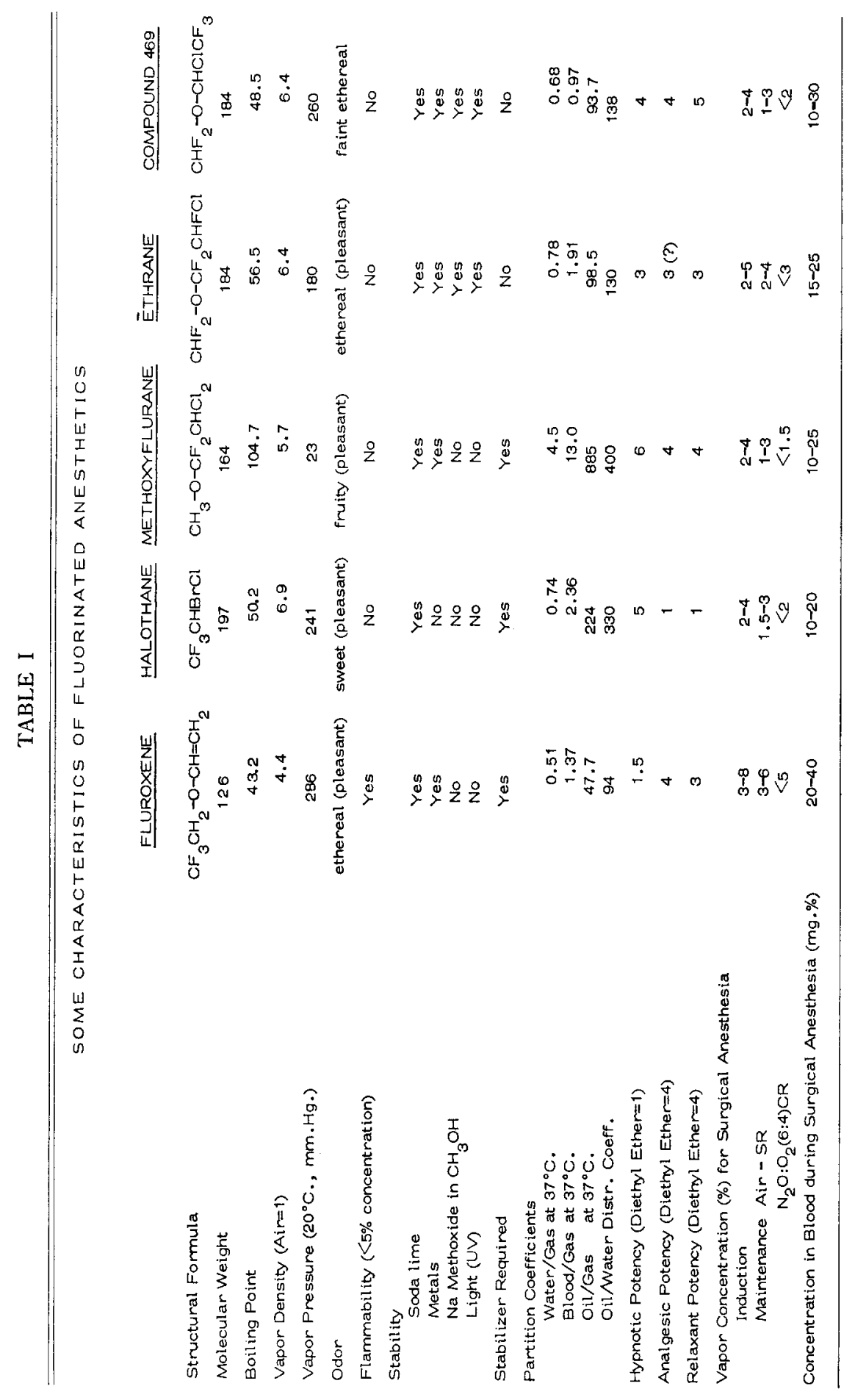


genated anaesthetics currently available, the following clinical evaluation was carried out with detailed physiological and biochemical monitoring.

\section{Materals and Methods}

A signed informed consent for clinical evaluation of this agent was obtained from each of 204 adult patients. There were 71 males and 133 females varying in age from 21 to 88 years, with a mean of 53 . The median physical state was Class II: 104 patients, with 46 each in Class I and Class III and 8 in Class IV. Operations performed included 16 neurosurgical, 13 intrathoracic, 104 intra-abdominal, 36 pelvic, and 35 superficial procedures, of which 176 were major interventions. The mean anaesthesia time was 178 minutes, with 28 operations less than one hour, 85 up to three hours, 80 up to 6 hours, and 11 up to 12 hours.

Premedication was atropine or scopolamine alone or combined with a modest dose of meperidine. Patients for minor pelvic operations ( $\mathrm{D} \& \mathrm{C}$ and related procedures) and relatively superficial operations (breast biopsy, femoral herniorrhaphy) were induced and maintained by spontaneous respiration from a face mask with 2:1 nitrous oxide-oxygen and Forane ( 1 to 3 per cent) dispensed from a recalibrated Fluotec vaporizer. Patients for major abdominal, thoracic, and neurosurgical procedures were induced with a sleep dose of thiopental with non-depolarizing muscle relaxant for intubation. They were maintained with 2:1 nitrous oxide-oxygen and Forane ( $<1.5$ per cent) in a semiclosed circle system with mechanically controlled respiration at a tidal volume of $10 \mathrm{ml} / \mathrm{kg}$ and respiratory rate of 12 to 16 per minute. When the deep structures were closed surgically, spontaneous respiration was allowed to resume as the nitrous oxide and Forane were gradually turned off. Vital signs (blood pressure, pulse rate, ECG, rectal temperature, urine output, electroencephalogram, haematology, and urinalysis) were monitored as previously reported.1,2,4 Arterial blood gases were monitored serially in 82 major cases (abdominal and thoracic surgery). Transaminases were measured in all cases. Blood chemistry was checked in over 100 major cases. The consumption of the liquid anaesthetic was measured in each case to determine the mean rate of utilization per minute.

All data pertinent to the evaluation of the anaesthetic agent were transferred to IBM data cards for subsequent tabulation, review, and comparison with anaesthetic agents previously studied.

\section{Results}

\section{Clinical observations}

The inhalation of Forane in rapidly increased vapor concentrations up to 3 per cent with nitrous oxide was described by the patients as very pleasant. It produced loss of awareness within two minutes, surgical anaesthesia in 3 to 5 minutes, and orolaryngotracheal relaxation sufficient to insert an endotracheal tube within 8 minutes, without provoking salivation, coughing, or breathholding; virtually no excitement stage occurred; skin was warm, dry, and of normal color; and pulse rate, electrocardiogram, and electroencephalogram were not notably changed. During induction, blood pressure fell slightly in the elderly, and the 
TABLE II

Effect on Blood Pressure and Pulse Rate (204 patients)

\begin{tabular}{lccccc}
\hline & $\begin{array}{c}\text { Before } \\
\text { induction }\end{array}$ & $\begin{array}{c}20 \mathrm{~min} \\
\text { after } \\
\text { induction }\end{array}$ & $\begin{array}{c}\text { End of } \\
\text { anaesth. }\end{array}$ & $\begin{array}{c}30 \mathrm{~min} \\
\text { later }\end{array}$ & $\begin{array}{c}60 \mathrm{~min} \\
\text { later }\end{array}$ \\
\cline { 2 - 5 } & & & & & \\
$\begin{array}{c}\text { Systolic } \\
\text { blood pressure }\end{array}$ & $139 \pm 22^{*}$ & $126 \pm 20$ & $140 \pm 23$ & $\mathbf{1 4 1 \pm 2 7}$ & $140 \pm 27$ \\
$\begin{array}{c}\text { Diastolic } \\
\text { blood pressure }\end{array}$ & $85 \pm 14$ & $80 \pm 15$ & $87 \pm 15$ & $86 \pm 14$ & $83 \pm 14$ \\
Pulse rate & $84 \pm 15$ & $90 \pm 14$ & $88 \pm 15$ & $85 \pm 15$ & $82 \pm 14$ \\
\hline *
\end{tabular}

rate and depth of respiration fell noticeably until surgical stimulation began. Concentrations of 0.5 to 1.5 per cent were sufficient to perform bimanual pelvic examination, uterine dilation and curettage, and superficial operations without depression of respiration or blood pressure. Pupils were usually constricted and fixed, and the conjunctivae became injected at a surgical depth of anaesthesia. Only one patient developed an arrhythmia on the ECG; during performance of a feeding gastrostomy, premature ventricular contractions appeared when traction was applied to the stomach (he had an invading and occluding carcinoma of the lower end of the oesophagus).

All of these patients recovered promptly and were not only wide awake, but quite lucid within 15 to 30 minutes of termination of anaesthesia.

During major operations, with mechanically controlled respiration, satisfactory surgical anaesthesia occurred when 0.5 to 1.5 per cent Forane was vaporized outside a semiclosed circuit with 2:1 nitrous oxide-oxygen. Vital signs (blood pressure and pulse rate see Table II), skinwarmth and moistness, and ECG lead 2 were virtually unaffected unless considerable surgical bleeding or strong visceral traction occurred. Hiccoughs were not observed in any of the 104 major abdominal operations. Airway secretions were minimal and there was no gross change in pulmonary compliance. EEG tracings usually appeared as slow, deep waves similar to the nitrous oxide "deep sleep" pattern. None of the tracings showed flattening or burst suppression. Unexplained excessive oozing of blood was not observed in the surgical wound. Muscular relaxation was adequate during all major intra-abdominal and intra-thoracic operations, unless the inhaled concentration of Forane was reduced below 0.5 per cent. Supplementary doses of muscle relaxant drugs were not required following intubation. Muscular twitching was not observed. Urine output was moderately reduced during surgery but responded to forced diuresis, and quickly returned to normal after surgery. Rectal temperature fell 1 to $2^{\circ} \mathrm{C}$ depending upon the duration of the operation.

On termination of anaesthesia, spontaneous respiration resumed rapidly in all but unexpectedly shortened operations where the action of a non-depolarizing muscle relaxant drug persisted. This effect was reversed effectively with neostigmine after atropine administration. Wakefulness and lucidity returned promptly, even in the 11 patients in whom the duration of operation exceeded 6 hours (Table III). 
TABLE III

ReCovery of WakefulNESS AFter SURGery

\begin{tabular}{rr}
\hline$<15 \mathrm{~min}$ & 134 patients $(66$ per cent) \\
$15-30 \mathrm{~min}$ & 31 patients (15 per cent) \\
$>30 \mathrm{~min}$ & 39 patients (19 per cent) \\
mean time 'eyes open': 11 minutes \\
mean time 'tongue out': 18 minutes \\
\hline
\end{tabular}

TABLE IV

Recovery of Respiration after Major Surgery

\begin{tabular}{lccccccc}
\hline \hline & $\begin{array}{c}\text { Radford } \\
\text { predicted } \\
\text { MV(L) }\end{array}$ & \multicolumn{2}{c}{$\begin{array}{c}\text { End of } \\
\text { anaesth. } \\
\text { RR }\end{array}$} & \multicolumn{2}{c}{$\begin{array}{c}30 \text { MVin } \\
\text { later }\end{array}$} & RR & \multicolumn{2}{c}{$\begin{array}{c}60 \mathrm{~min} \\
\text { MV(L) }\end{array}$} & \multicolumn{2}{c}{ RR } & MV(L) \\
\cline { 2 - 9 } Mean & 6.27 & 20 & 8.33 & 21 & 8.08 & 21 & 8.98 \\
SEM & 0.11 & & 0.39 & & 0.31 & & 0.30 \\
\hline
\end{tabular}

TABLE $\mathrm{V}$

Blood Gas and Related Data (82 patients)

\begin{tabular}{|c|c|c|c|c|c|c|c|c|}
\hline & & Control & $\begin{array}{l}\text { Before } \\
\text { induction }\end{array}$ & $\begin{array}{l}\text { During } \\
\text { anaesth.* }\end{array}$ & $\begin{array}{l}\text { End of } \\
\text { anaesth. }\end{array}$ & $\begin{array}{l}30 \mathrm{~min} \\
\text { later }\end{array}$ & $\begin{array}{c}60 \mathrm{~min} \\
\text { later }\end{array}$ & $\begin{array}{c}24 \mathrm{hrs} \\
\text { later }\end{array}$ \\
\hline $\mathrm{pH}$ & SEM & 7.45 & 7.46 & 7.50 & 7.43 & 7.44 & 7.45 & 7.49 \\
\hline $\mathrm{PaCO}_{2}$ & SE:12 & $35^{.04}$ & $33^{.04}$ & 28 & 35 & $34^{\circ}$ & 33 & 31.00 \\
\hline (1) & SEM & 4 & 4 & 7 & 8 & 6 & 6 & 4 \\
\hline $\begin{array}{l}\mathrm{HCO}_{3} \\
\mathrm{PaO}_{2}\end{array}$ & & $\begin{array}{l}23 \\
70\end{array}$ & $\begin{array}{l}22 \\
64\end{array}$ & $\begin{array}{r}21 \\
126\end{array}$ & $\begin{array}{r}22 \\
289\end{array}$ & $\begin{array}{l}22 \\
85\end{array}$ & $\begin{array}{l}21 \\
71\end{array}$ & $\begin{array}{l}23 \\
59\end{array}$ \\
\hline & SEM & 10 & 11 & 47 & 114 & 30 & 20 & 8 \\
\hline $\mathrm{SaO}_{2}$ & & 95 & 94 & 96 & 98 & 94 & 94 & 93 \\
\hline Hct & SEM & $\begin{array}{r}2 \\
37\end{array}$ & $\begin{array}{r}2 \\
37\end{array}$ & $\begin{array}{r}2 \\
36\end{array}$ & $\begin{array}{r}2 \\
37\end{array}$ & $\begin{array}{l}3 \\
38\end{array}$ & $\begin{array}{r}3 \\
38\end{array}$ & $\begin{array}{r}3 \\
36\end{array}$ \\
\hline & SEM & 5 & 5 & 5 & $\tilde{5}$ & 5 & $\tilde{5}$ & 5 \\
\hline
\end{tabular}

*mean of hourly samples.

In most cases pulmonary ventilation, as measured with a Wright Respirometer, returned to normal in less than 30 minutes, along with the ability to raise the head, protrude the tongue, cough on command, and converse clearly. Recovery of wakefulness was complete and sustained. Blood pressure and pulse rate remained stable in the recovery room. None of the patients was restless or delirious during emergence and, although they were lucid, they did not request or require medication for pain in many cases until their return to the ward (Table IV).

Shivering was seen in only 4 patients ( 2 per cent) following surgery. Nausea and/or vomiting occurred in 12 of 71 males ( 17 per cent) and in 37 of 133 females ( 28 per cent). The overall incidence during the first 24 hours was 24 per cent and, of these, one-third had recurrent symptoms.

The amount of Forane utilized on the average was $27 \mathrm{ml}$ per hour during 600 hours of use in a semiclosed anaesthesia system with a mean total gas flow of 10 liters per minute. 
TABLE VI

(A) Blood Chemistry (mean \pm sem)

\begin{tabular}{lccc}
\hline \hline \multicolumn{1}{c}{ Test } & $\begin{array}{c}\text { No. of } \\
\text { patients }\end{array}$ & Before & After \\
\hline SGOT units & 203 & $19 \pm 1$ & $32 \pm 2$ \\
SGPT units & 203 & $20 \pm 1$ & $28 \pm 2$ \\
BUN mg per cent & 106 & $19 \pm 1$ & $19 \pm 1$ \\
Creatinine mg per cent & 106 & $1.03 \pm .05$ & $1.06 \pm .05$ \\
Sodium mEq/L & 106 & $136 \pm 6$ & $133 \pm 7$ \\
Potassium mEq/L & 106 & $3.7 \pm 0.4$ & $3.5 \pm 0.5$ \\
Calcium mEq/L & 106 & $4.1 \pm 0.5$ & $3.9 \pm 0.5$ \\
\hline
\end{tabular}

TABLE VII

(B) Blood Chemistry (MeAN \pm SEM)

\begin{tabular}{lccc}
\hline \multicolumn{1}{c}{ Test } & $\begin{array}{c}\text { No. of } \\
\text { patients }\end{array}$ & Before & After \\
\hline Glucose mg per cent & 106 & $122 \pm 9$ & $213 \pm \mathbf{1 6}$ \\
Inorganic phosphorus mg per cent & 106 & $3.5 \pm 0.1$ & $3.4 \pm 0.1$ \\
Histamine $\mu \mathrm{g} / \mathrm{L}$ & 30 & $20 \pm 2$ & $18 \pm 1$ \\
Serotonin $\mu \mathrm{g} / \mathrm{L}$ & 30 & $122 \pm 11$ & $117 \pm 12$ \\
Cortisol $\mu \mathrm{g}$ per cent & 106 & $12 \pm 1$ & $30 \pm 2$ \\
Epinephrine $\mu \mathrm{g} / \mathrm{L}$ & 106 & $.40 \pm .12$ & $.58 \pm .11$ \\
Norepinephrine $\mu \mathrm{g} / \mathrm{L}$ & 106 & $.51 \pm .10$ & $.93 \pm .13$ \\
\hline
\end{tabular}

\section{Laboratory observations}

Serial blood gas measurements during 82 major operations indicated that metabolic acidosis did not occur. Postoperatively only the usual moderate reduction of oxygen tension was seen after major intra-abdominal and intrathoracic operations (Table V).

There was a rise in the white blood count and polymorphonuclear leucocytes after most major operations. Blood electrolytes ( $\mathrm{Na}, \mathrm{K}$, and $\mathrm{Ca}$ ) did not change significantly; inorganic phosphorus, creatinine and Bus did not change. Transaminases rose transiently. Histamine and serotonin did not change appreciably. Blood glucose rose more than 75 per cent in most patients, plasma cortisol was usually at least doubled, and total catecholamines were usually increased about 50 per cent ( Tables VI and VII).

\section{ComMents}

Forane resembles methoxyflurane chemically and as an anaesthetic, although its physical properties and speed of action are closer to that of halothane.,4 Based on liquid anaesthetic consumption rates, Forane is approximately 15 per cent more potent than $\vec{E}$ thrane, which is half as potent as methoxyflurane. However, the minimum alveolar concentration value reported is appreciably lower for methoxyflurane ( 0.25 per cent $)^{5}$ than for Ethrane (2.1 per cent) and Forane (1.5 per cent) ${ }^{6}$

Clinically, Forane was distinguishable from Ethrane by its fainter odor, greater hypnotic and relaxant potency, and an analgesic action which persisted after 
wakefulness returned. Although our animal studies indicated greater stability of the ECG and somewhat greater hypotension during induction of anaesthesia, this difference was not evident clinically. As observed in the animal studies, Forane differed clinically from Ethrane in lacking any irritant effect on the neuromuscular system and on the EEG. ${ }^{1,3,4}$ Both these compounds appeared to have marked potentiating effect on non-depolarizing muscle relaxants. ${ }^{1,4}$

Forane is similar to Ethrane in causing a sharp rise in blood sugar and moderate rise in plasma norepinephrine, which is not usually evident with halothane and methoxyflurane. On the other hand, all four agents cause an appreciable elevation of white blood counts and plasma cortisol. ${ }^{1,7}$ Otherwise, alterations in blood chemistry due to these agents are minimal and do not indicate adverse effects to vital organs. ${ }^{2,3,8}$

Based on this study, we believe that Forane is a safe, effective anaesthetic worthy of further clinical evaluation.

\section{RÉsumé}

Un analogue de l'éthrane connu sous le nom de forane (composé 469), dont la formule chimique est $\mathrm{CHF}_{2}-\mathrm{O}-\mathrm{CHCLCF}_{3}$, a été évalué cliniquement associé au protoxyde d'azote-oxygène $(2: 1)$ chez 204 adultes volontaires. Cet agent est un éther fluoré non explosif, à l'odeur douce et agréable; à la concentration de 0.5 à 3.0 pour cent, il produit une anesthésie complète doucement et rapidement sans période d'excitation. Il est compatible avec les produits adjuvants utilisés durant l'anesthésie, mais il potentialise de façon marquée les myorésolutifs non dépolarisants. La pression sanguine, le rythme du pouls, l'ECG et l'Eeg sont stables durant Tanesthésie chirurgicale, alors que la ventilation pulmonaire est déprimée et demande d'être assistée durant les opérations viscérales majeures. Le débit urinaire est légèrement diminué. Les analyses chimiques du sang, l'hématologie et l'étude des gaz sanguins indiquent que cet agent ne cause pas de troubles métaboliques. Le réveil est doux et rapide et un certain degré d'analgésie persiste durant ce stage. Le hoquet et le frisson sont rares, alors que les nausées et les vomissements ne sont pas exagérés. Dans notre étude, nous n’avons pas eu de complications post-opératoires attribuables à cet agent. Le forane mérite une étude clinique approfondie.

\section{REFERENCES}

1. Dobkin, A. B.; Heinrich, R. G.; Isfaer, J. S.; Levy, A. A.; Neville, J. R., Jr. \& OunkaSEM, K. Clinical and laboratory evaluation of a new inhalation agent: Compound $347 \mathrm{CHF}_{2}-\mathrm{O}-\mathrm{CF}_{2} \mathrm{CHFCl}$. Anesthesiology. 29: 275 (1968).

2. Byles, P. H.; Dobkin, A. B.; Ferguson, J. H.; \& Levy, A. A. Laboratory evaluation of 1-chloro-2,2,2-trifluorethyl difluoromethyl ether (Compound 469). ASA Abstracts of Scientific Papers, Annual Meeting, 25-29 October 1969.

3. Byles, P. H.; Dobkin, A. B.; \& Jonks, D. B. A comparison of the effects of a new inhalation agent, Compound 469, with those of halothane, methoxyllurane, and Ethrane on hepatic and renal pathology and blood chemistry in animals. Unpublished report.

4. Dobkin, A. B.; Nishioka, K.; Gengage, D. B.; Kim, D.S.; Evers, W.; \& Israel, J. S. $\overrightarrow{\mathrm{E}}$ thrane (Compound 347) anaesthesia: a clinical and laboratory review of 700 cases. Anesth. \& Analg. 48: 477 (1969). 
5. Samman, L. J.; Eger, E. I., iI; Munson, E. S.; Babad, A. B.; \& Muallem, M. Minimum alveolar concentrations of methoxyflurane, halothane, ether, and cyclopropane in man: correlation with theories of anesthesia. Anesthesiology. 28: 994 (1967).

6. Eger, E. I. II. Personal communication.

7. Nishioka, K.; Levy, A. A.; \& Dobkin, A. B. Effect of halothane and methoxyflurane anaesthesia on plasma cortisol concentration in relation to major surgery. Canad. Anaesth. Soc. J. 15: 441 (1968).

8. Stevens, W. C.; Joas, T. A.; \& Eger, E. I., II. A comparison of hepatic and renal toxicity associated with Ethrane, Compound 469, halothane, and chloroform anesthesia in dogs. AsA Abstracts of Scientific Papers, 1969 Annual Meeting. 